\title{
New data concerning the distribution, behaviour, ecology and taxonomic relationships of Minas Gerais Tyrannulet Phylloscartes roquettei
}

\author{
MARCOS A. RAPOSO, JUAN MAZAR BARNETT, GUY M. KIRWAN and \\ RICARDO PARRINI
}

\begin{abstract}
Summary
We report new observations of the globally threatened Minas Gerais Tyrannulet Phylloscartes roquettei from two areas in the São Francisco Valley, Minas Gerais, Brazil, between July 1993 and February 2002. Four pairs, one fledged young and two lone individuals were observed in the course of our fieldwork. It was previously known only from a female taken in the mid-1920s and sight records and tape-recordings in 1977. Our records extend the species' known range $250 \mathrm{~km}$ south and west of the type-locality region. Details of the first-known male specimen are presented, along with novel data concerning its vocalizations and behaviour. We draw attention to the possible relationship of the species to a group of four other Phylloscartes tyrannulets with similarly patterned faces and overall plumage, which exhibit a similar circum-Amazonian distribution pattern to three Phyllomyias tyrannulets. We also take the opportunity to draw more attention to the imperilled conservation status of the dry forests upon which $P$. roquettei and a host of other threatened and Near-threatened avian taxa depend.
\end{abstract}

\section{Resumo}

São apresentadas novas observações sobre a espécie pouco conhecida e ameaçada Phylloscartes roquettei, endêmica do vale do rio São Francisco, Minas Gerais, Brasil, realizadas entre os anos de 1993 e 2002. Essa espécie era, previamente, conhecida somente de uma fêmea coletada em meados da década de 1920 e de observações realizadas em 1977. Estas novas observações ampliam a distribuição da espécie em cerca de $250 \mathrm{~km}$ a sul e a leste da localidade de onde provém o holótipo. É apresentada uma descrição do primeiro espécime macho conhecido e detalhes de hábitos e vocalização da espécie. Chama-se a atenção para uma possível proximidade filogenética de Phylloscartes roquettei com um grupo formado por quatro outras espécies de Phylloscartes com padrão geral semelhante de plumagem. Além disso, propõe-se que o grupo formado por essas cinco espécies apresenta distribuição circum-amazônica semelhante à apresentada por um grupo de três espécies pertencentes ao gênero Phyllomyias. Ao final do artigo, chama-se a atenção, mais uma vez, para a importância da conservação das florestas secas associadas ao rio São Francisco, formações ricas em endemismos de aves.

\section{Introduction}

Minas Gerais Tyrannulet Phylloscartes roquettei is a globally threatened Brazilian endemic that was described on the basis of a single female collected at Brejo 
Januária (c. $15^{\circ} 29^{\prime} \mathrm{S}, 44^{\circ} 22^{\prime} \mathrm{W}$ ), Minas Gerais, on the left bank of the rio São Francisco, on 3 July 1926 (Collar et al. 1992). The species was subsequently recorded by Willis and Oniki (1991) in dry forests on both sides of the rio São Francisco in September 1977 but has since gone unreported. Its threat status is currently considered Critical (BirdLife International 2000). Despite the rediscovery by Willis and Oniki (1991), virtually nothing is known of this species in life (Collar et al. 1992, Ridgely and Tudor 1994) and its known distribution is confined to the type-locality and close environs.

Here, we present details of our observations from recent visits by ourselves and co-workers to municipalities south of the type-locality, which appear highly pertinent to a revision of its systematic and biogeographical affinities, and also evaluate its conservation status, presenting recommendations for future action. A male specimen was taken, which we compared with the holotype, a female, housed at Museu Nacional de Rio de Janeiro (MNRJ 12628; Snethlage 1928). We thus provide the first description of a male.

\section{Study area and methods}

We principally surveyed two municipalities in the middle reaches of the São Francisco Valley, Minas Gerais: Várzea da Palma, south-east of Pirapora (c. $17^{\circ} 21^{\prime} \mathrm{S} 44^{\circ} 56^{\prime} \mathrm{W}$ and $c .17^{\circ} 23^{\prime} \mathrm{S} 44^{\circ} 48^{\prime} \mathrm{W}$; RP in July 1993, Heinz Remold and Edwin O. Willis on 12-13 November 1998, JMB and GMK in mid-December 1999 and GMK in February 2002), and Francisco Dumont (c. $17^{\circ} 26^{\prime} \mathrm{S} 44^{\circ} \mathrm{O} 7^{\prime} \mathrm{W}$; MAR in November 1995). At Várzea da Palma observations were made in patches of dry forest and gallery forests fringing the rio das Velhas, a tributary of the rio São Francisco, and the Córrego dos Ovos, a small tributary of the rio das Velhas. At Francisco Dumont MAR made observations in dry forests and gallery forests associated with the rio Jequitaí, on the right margin of the São Francisco. The study localities are mapped in Figure 1.

Our fieldwork totalled 25 days, 10 at Várzea da Palma and 15 at Francisco Dumont. During our visits to this region of northern Minas Gerais we made opportunistic observations on $P$. roquettei during the course of general avifaunal inventory work at various localities in the rio São Francisco Valley (see e.g. Kirwan et al. 2001). Fieldwork was concentrated within (but not restricted to) the first and last three hours of daylight each day. Vocalizations were recorded by David Beadle, JMB and MAR using Sony TCM-50oo tape-recorders and Sennheiser ME-66 microphones (and also by Jeremy Minns in mid-December 1999 and February 2002 using a Sony TCD-DioPro II DAT recorder and Sennheiser ME-66 microphone). Voucher recordings by the last three-named recordists have been or will be deposited at the Library of Natural Sounds, Cornell Laboratory of Ornithology, Ithaca, New York and the Arquivo Sonoro Elías Coelho, Universidade Federal do Rio de Janeiro, Brazil, and those by Minns also in the National Sound Archive, London, U.K.

In general, the areas we surveyed were covered by low caatinga-type scrub (i.e. spiny trees and bushes that have pale grey branches and which are leafless in the dry season) and to a lesser extent degraded deciduous forest. Otherwise, agricultural landscapes predominate. The area had formerly been noted for a 


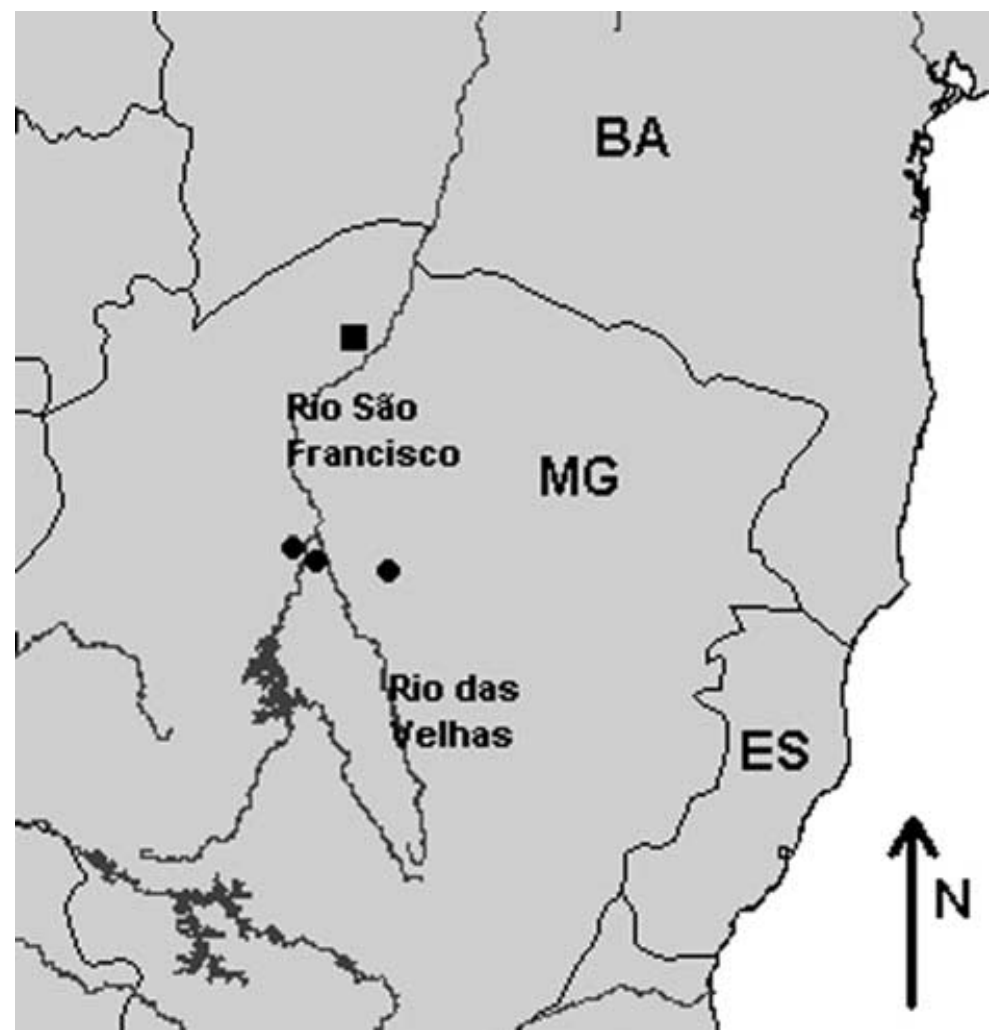

Figure 1. Map of the localities where Minas Gerais Tyrannulet Phylloscartes roquettei has been recorded in Minas Gerais (MG) state, south-east Brazil. The other states mapped are Bahia (BA) and Espírito Santo (ES). The square represents Brejo Januária, the type-locality, and the circles represent the new records: left and centre, Várzea da Palma; and right, Francisco Dumont.

greater variety of habitats and Hartt (1870) described rich forests (now gone) in the vicinity of the lower rio das Velhas.

Both localities are within the sedimentary basin of the São Francisco, characterized by the presence of limestone, which forms a layered substrate that is frequently explored by mining companies. Extensive dry forests grow on these areas, with "barrigudas" (Chorisia sp.) common among other species of tree characteristic of the central Brazilian deciduous forests.

A male specimen was acquired during the course of fieldwork at Francisco Dumont. In preparing a plumage description of this bird (see Morphology and plumage description) we have followed Smithe (1975), using his capitalized colour names and numbers.

\section{Results}

Behaviour and habitat preferences

Four pairs, one fledged young and two lone individuals of $P$. roquettei were observed during the course of the authors' fieldwork, in dry and gallery forests 
associated with the river courses mentioned above. In addition, Remold and Willis observed two (perhaps a pair) in gallery forest in the same area as observations by RP, GMK and JMB, on 12-13 November 1998. Despite previous reports of the species to be most frequently associated with dry forests at the margins of the São Francisco (Collar et al. 1992), our observations demonstrate that it also occurs in related habitats and Willis and Oniki (1991) also found it away from the river, atop an escarpment in one instance. Its use of these related habitats was especially true at Francisco Dumont and Córrego dos Ovos, where it was always found within very narrow strips of gallery forest (at the latter locality always within the same tiny patch of trees, except in February 2002 when a pair was also discovered in tall semi-deciduous forest around a fazenda building c. $1 \mathrm{~km}$ from the Córrego dos Ovos). In dry and gallery forests, P. roquettei preferred tall emergent trees, which were probably remnants of the original vegetation, only appearing as emergents due to degradation of the surrounding vegetation.

In dry forests associated with the rio das Velhas (on its left margin, $15 \mathrm{~km}$ north of Várzea da Palma), a presumed pair was observed on a $c .20 \mathrm{~m}$ tall "jatobá" (Hymenaea sp.) for more than 15 minutes (MAR made similar observations at Francisco Dumont). The tree was fruiting and lacked foliage. During this period, they caught arthropods among the lower branches; they subsequently descended to a lower, more open area $(2-3 \mathrm{~m})$ with dense green foliage in the same tree. Thereafter, both flew to another jatobá where they remained for a short period, repeating the movements described above. An individual attracted to playback in the early afternoon of 17 December 1999 approached from the treetops of gallery forest flanking the Córrego dos Ovos, and perched atop low trees at the forest edge. The following morning, what was presumably the same individual kept high in the canopy, calling for long periods though otherwise comparatively inactive. In February 2002 GMK observed a family party of three birds, a second pair and one lone individual behaving in a similar manner and, except when responding to playback, always remaining at 5-10 $\mathrm{m}$ in the midcanopy or higher. The birds observed by Remold and Willis never descended from the canopy of taller trees, but Willis and Oniki reported birds descending low down in a cotton Gossypium field.

All adopted a posture with the body pointing forwards (at approximately $45^{\circ}$, but also more horizontal) and the wings held drooped, similar to that of Mottle-cheeked Tyrannulet $P$. ventralis, but also occasionally raising but never fully extending their wings quickly (one closely observed individual consistently raised the left wing first, and did not always raise the other wing thereafter). They consistently held their tails slightly above the horizontal and frequently performed shallow tail-bobbing movements, without obvious synchrony with the wing raising and drooping. The tail, however, never appeared to reach an angle perpendicular to the body, as occurs in some congeners (e.g. Oustalet's Tyrannulet $P$. oustaleti). These observations apparently coincide with those of Willis and Oniki (1991) from around Januária, and very similar behavioural characteristics have been reported for P. parkeri (Fitzpatrick and Stotz 1997).

Prey was captured mainly by aerial pursuit among, only occasionally away from, the upper branches of large, sometimes isolated trees, but also by infre- 
quently pecking at food items on the surface of the few remaining green leaves of trees otherwise devoid of foliage. In the latter, individuals performed "reach" manouevres or short "sally-strikes" (Remsen and Robinson 1990). Flights were relatively frequent and always performed asynchronously by members of a pair. Generally, they left a higher perch and flew diagonally down, suddenly looping back and perching on a lower branch, usually within the same tree. Flights were of a maximum of $1 \mathrm{~m}$ and no wing noise was perceivable, as occurs for example in P. ventralis (all authors pers. obs.) or P. parkeri (Fitzpatrick and Stotz 1997). The flight and "loop" pattern is sufficiently characteristic and frequent that it comprises one of the most conspicuous features of the species in the field, being noticeable at considerable distance (at least in June, November and February). In December, short flights between branches within the canopy were noted and the family party observed in February always remained in close proximity of one another within the same tree, except when responding to playback. The species was never observed within mixed-species flocks, but this behaviour was observed by Willis and Oniki (1991), though we have witnessed them sharing space equally with other foraging Tyrannidae, most frequently Planalto Tyrannulet Phyllomyias fasciatus and Yellow-olive Flycatcher Tolmomyias sulphurescens, within emergent trees.

Most Phylloscartes flycatchers frequently attend mixed-species flocks. P. parkeri virtually always occurs in mixed-species flocks (Fitzpatrick and Stotz 1997), as does P. sylviolus (Clay et al. 1998; all authors pers. obs.). Our personal knowledge of $P$. superciliaris is non-existent and very limited concerning P. flaviventris, though both appear to be habitual flock members, like their congenerics, based upon the literature (Wetmore 1972, de Schauensee and Phelps 1978, Hilty and Brown 1986, Stiles and Skutch 1989). Our observations of $P$. roquettei are therefore surprising in this respect. We have specifically searched for it within mixedspecies flocks at both known localities and at nearby sites without success (see Other fieldwork). Further and more detailed observations are clearly required to establish the true extent of its flocking behaviour.

The only specific interaction we have observed with other species concerns one of the family party watched in February 2002 which was repeatedly chased by a Glittering-throated Emerald Amazilia fimbriata over the course of several minutes. Another hummingbird, Planalto Hermit Phaethornis pretrei, also present in the same restricted area, was not observed to interact with $P$. roquettei.

\section{Vocalizations}

P. roquettei song consists of a fast series of harmonic notes (Figure 2) and distantly resembles that of White-crested Tyrannulet Serpophaga subcristata. In addition to the song, it frequently delivers other vocalizations, which vary from a phrase similar to an incomplete version of the song, to calls consisting of two or three notes, but also similar to those given during the song, described by Remold as "a faint peep". These "contact" calls are delivered more or less continuously while foraging, but are very inconspicuous due to their speed, low volume and the height at which the species frequently feeds. In general structure, the song resembles that of $P$. parkeri, as can be clearly perceived from the sonograms presented by Willis and Oniki (1991) and Fitzpatrick and Stotz (1997). 


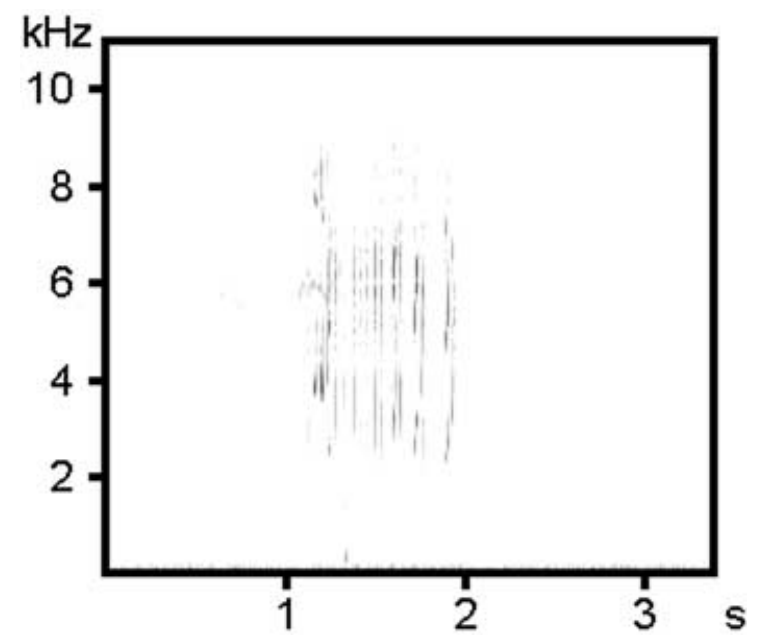

Figure 2. Song of Minas Gerais Tyrannulet Phylloscartes roquettei recorded by Marcos A. Raposo, at Francisco Dumont, Minas Gerais, in November 1995.

\section{Morphology and plumage description}

The male specimen taken on 19 November 1995 at Francisco Dumont (MNRJ 42728) was an adult, with ossified skull, total length of $115 \mathrm{~mm}$ and weight $6 \mathrm{~g}$. The bill was 10 $\mathrm{mm}$ long, the wing $50 \mathrm{~mm}$ and tail $49 \mathrm{~mm}$. Measurements of the female (the holotype, MNRJ 12628) were: bill $9 \mathrm{~mm}$; wing $44.5 \mathrm{~mm}$; tarsus 13 $\mathrm{mm}$ and tail $41 \mathrm{~mm}$ (several rectrices lost). One congener of $P$. roquettei exhibits some sexual dimorphism in respect of size (males of $P$. parkeri are between $7 \%$ to $9 \%$ larger than females; Fitzpatrick and Stotz 1997) and it is possible that $P$. roquettei shares this feature. It is noteworthy, given that the female has lost most of its tail feathers, that it nonetheless appears short-tailed, which is obviously a false impression for the species based on the male specimen and the appearance of individuals we have observed in the field.

The male has a black bill with ashy base to the lower mandible; lores and forehead Yellow-Ochre ( $123 \mathrm{C}$ though appearing slightly rusty in the field depending on light conditions); periophthalmic region with a thin line of Sulphur-Yellow (157) reaching the ear-coverts; crown, mantle, back and rump Bunting-Green (150) slightly washed yellow; leading edge of remiges and upperwing-coverts black with contrasting sulphur-yellow terminal bands, which form two faint wingbars, but no wing panel; rectrices dark BrownishOlive (129) with fringes also yellow; entire underparts sulphur-yellow with breast somewhat more ochre tinged; tarsus Vandyke-Brown (121) and soles of feet ochre. In the field, the iris appeared dark and the mandible pale pinkish.

At least one of those observed in February 2002 was in extensive tail moult (only the central pair of rectrices were full) and there was evidence of bodyfeather moult in the same individual. 


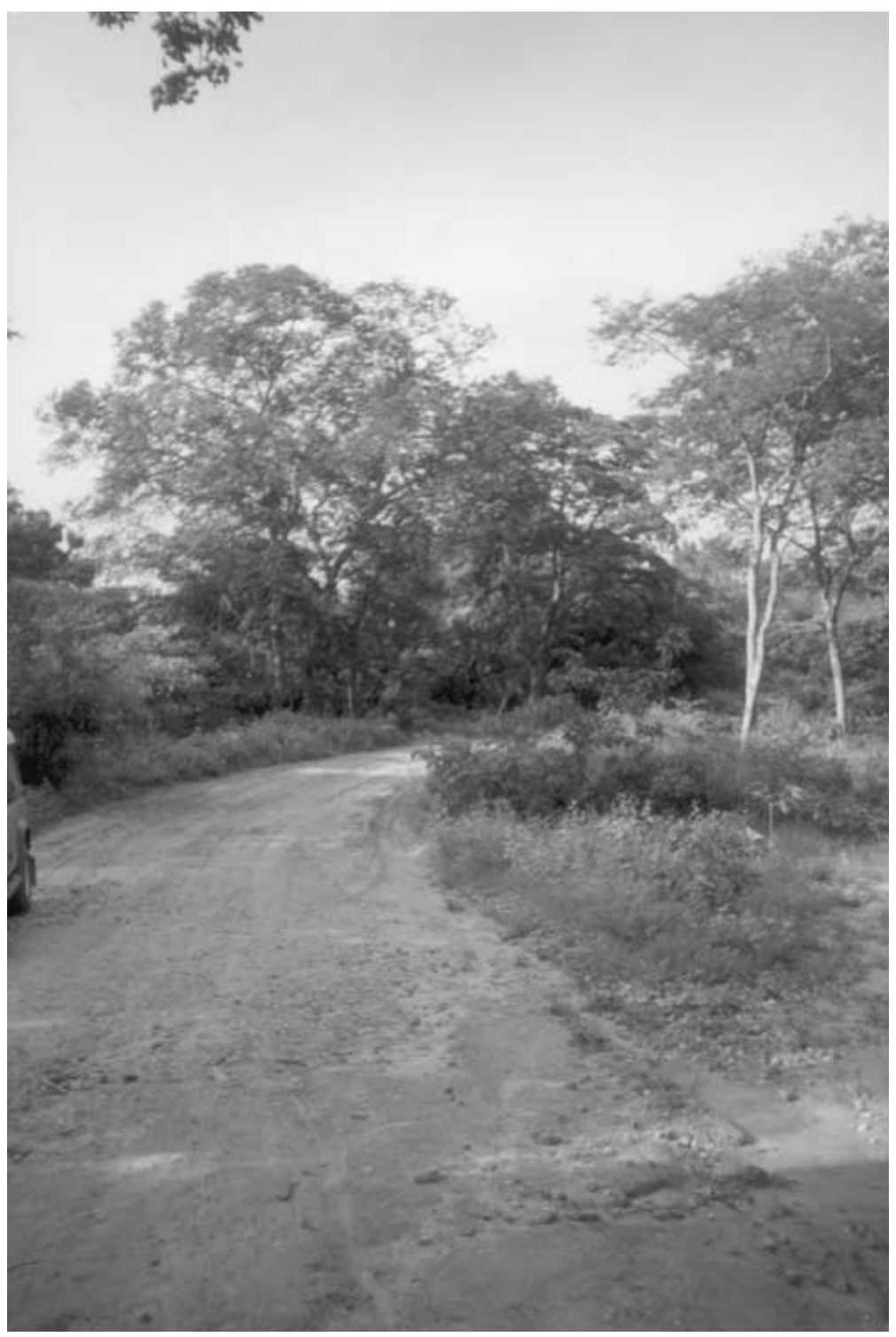

Figure 3. Forest fringing the Córrego dos Ovos, Várzea da Palma, Minas Gerais, February 2002. This small patch of trees has been consistently occupied by a pair of Minas Gerais Tyrannulet Phylloscartes roquettei in recent years. (Photograph by Guy M. Kirwan.)

\section{Other fieldwork}

Phylloscartes roquettei is known from only three recent localities and we unsuccessfully searched for it at additional sites. The first was a small patch of tall humid woodland c. $30 \mathrm{~km}$ north of Pirapora, on the road to Montes Claros, Minas Gerais, which we investigated on 18 December 1999. For approximately 45 minutes we searched for the species, using playback of its vocalization. The second is the Cavernas do Peruaçu National Park and adjacent Fazenda Nossa 
Senhora Aparecida, near Itacarambí, Minas Gerais, visited by JMB, GMK and others (see Acknowledgements) on 10-11 March 1997, 8 November 1998, 18-21 December 1999 and 9 February 2002. These support deciduous or humid forests, and playback was again used in fruitless efforts to find the species. Finally, GMK and others searched (again using playback) for the species in semi-deciduous gallery woodland (up to $10 \mathrm{~m}$ tall), at the left bank of the São Francisco, centred on $15^{\circ} 36^{\prime} \mathrm{S} 44^{\circ} 26^{\prime} \mathrm{W}$, 1o km south of Januária, Minas Gerais, on 1o February 2002. The patches of woodland were surrounded by heavily degraded cerrado and cornfields but nevertheless appeared suitable for the species.

\section{Discussion}

\section{Relationships and biogeography}

The species' natural history is extremely poorly known and very little has been published concerning its phylogenetic relationships and biogeography. Silva (1989) suggested a relationship between P. roquettei and Rufous-lored Tyrannulet P. flaviventris of coastal and perhaps western Venezuela (Ridgely and Tudor 1994, but see comments in Fitzpatrick and Stotz 1997), including within his analysis a specimen from Cuzco, Peru, taken in 1899, which subsequently proved to be an example of the recently described Cinnamon-faced Tyrannulet $P$. parkeri known from south-east Peru and adjacent northern Bolivia (Fitzpatrick and Stotz 1997, see also Ridgely and Tudor 1994). The distributions of these three forms closely match those of three other taxa that have been considered near relatives: Reiser's Tyrannulet Phyllomyias reiseri, Sclater's Tyrannulet P. sclateri and Urich's (Greenish) Tyrannulet P. (virescens) urichi (Silva 1996, Kirwan et al. in press). A strong case can be made on morphological and biogeographical grounds that Phylloscartes parkeri is closely related to $P$. roquettei. The two are strikingly similar (see frontispiece in Fitzpatrick and Stotz 1997 and that paper for the only available depiction of parkeri), both in overall plumage and morphology, though parkeri possesses a greyish-grey crown, which is absent in roquettei, and paler yellow underparts than the latter. Similarities in behaviour and vocalizations are noted above. These taxa appear to form part of a group of Phylloscartes that have reddish or buff patterns in the forehead region and would also include P. superciliaris, which occurs disjunctly from north-west Venezuela and north Colombia south through the Andes of south-east Ecuador, as well as in Panama and Costa Rica (Ridgely and Tudor 1994), and P. flaviventris, for which a close relationship was already suggested by Fitzpatrick and Stotz (1997). Our analysis suggests that an additional species also appears to be part of this "group" based on morphology and behaviour (e.g. its preference for the canopy, feeding strategy and general vocalization patterns). This is Bay-ringed Tyrannulet $P$. sylviolus from the Atlantic Forest of south-east Brazil to extreme north-east Argentina and eastern Paraguay (Clay et al. 1998). Fitzpatrick and Stotz (1997) noted the morphological similarities between P. sylviolus and P. roquettei and the Andean group, but suggested that the two former taxa were probably not closely related to the other three because they lacked the particularly bold face patterns of the latter group. Nonetheless, we consider that a close relationship for these five Phylloscartes appears valid, which was subsequently supported by D. F. Stotz (in litt. 2001). 
The relative strength of their face patterns appears less important than the comparative similarity in their colorations, which automatically isolates them among congenerics, while their relative distributions strongly mirror those of the three Phyllomyias species closely related to Greenish Tyrannulet Phyllomyias virescens, whose distribution broadly overlaps that of Phylloscartes sylviolus. This hypothesis of a relationship between these five Phylloscartes, based solely on broad comparisons, should be tested through a comprehensive phylogenetic analysis. However, it appears strong on the basis of similarities in vocalization patterns (see Vocalizations), and their gnatcatcher-style foraging behaviour previously noted by Fitzpatrick and Stotz (1997) and, partially, by Clay et al. (1998) (see Behaviour and habitat preferences), as well as morphology and canopy preference. Such methods may also shed light on the relationships of this group to other Phylloscartes taxa, and test the validity of the genus Leptotriccus that is available for the group.

We suggest that the same biogeographical pattern described for the Phyllomyias group (Kirwan et al. 2001) can be identified among the species of Phylloscartes thought to be closely related to P. roquettei (Silva 1989, this work). Silva (1989) suggested a model for this species and Knipolegus franciscanus, whereby the forests inhabited by these taxa expanded during the most recent glacial period, as suggested by $\mathrm{Ab}^{\prime}$ Saber (1977). These forests became fragmented upon a return to more humid climates during the early Holocene (Silva 1989). Pennington et al. (2000) remarked upon the close relationship between all, currently isolated, patches of dry vegetation in South America, and suggested a former continuity between such relict vegetational fragments. Silva (1992) also emphasized the key role that Plio-Pleisticene tectonism has played in the origin of some central Brazilian taxa. Here, uplift and late orogenesis of the Brazilian shield and the Andes, combined with the subsidence of the Chaco lowlands, separated original stocks. The two processes, which are likely to have had similar net results, are radically different in age; thus a molecular perspective should provide the temporal scale required to broadly date the split between these forms. Should this group of Phylloscartes species prove to be monophyletic, it would represent a fine example of a taxon with a circum-Amazonian distribution pattern (Remsen et al. 1991).

While some previous works have demonstrated a key biogeographical role for the São Francisco, it being in some instances a geographical barrier responsible for differentiation among taxa, such as Lepidocolaptes squamatus and L. wagleri, presumably during the formation of its present-day course in the Pleistocene (Ab'Saber 1964, Silva and Straube 1997) and Xiphocolaptes albicollis and X. falcirostris (Silva and Oren 1997), the region can alternatively be considered a centre of endemism, as noted by Stattersfield et al. (1998) and Whitney et al. (in press).

\section{Conservation status and future action}

Minas Gerais Tyrannulet is globally threatened, being considered Critical (BirdLife International 200o), and although it can appear locally common, its habitat is being severely degraded. Ratter et al. (1978), Silva (1997), Silva and Oren (1992, 1997) and Silva and Straube (1997) have all highlighted levels of destruction and the precarious conservation status of habitats in the São Francisco basin; the main threats being forest clearance for agriculture, charcoal and 
timber extraction, as well as limestone quarrying. One of the largest irrigation projects in Latin America is underway in this region, the "Projeto Jaíba", in the process of which large areas have already been denuded of their native forests (Pimentel 1997, Raposo 1997, Ribon and Simon 1997). The range of P. roquettei is included within Endemic Bird Area (EBA) 074, Deciduous forests of Minas Gerais and Goiás (Stattersfield et al. 1998), which harbours other globally threatened species such as Golden-capped Parakeet Aratinga auricapilla, Pfrimer's Conure Pyrrhura pfrimeri, Moustached Woodcreeper Xiphocolaptes falcirostris, Caatinga Black-tyrant Knipolegus franciscanus and São Francisco Sparrow Arremon franciscanus, along with several Near-threatened species (see Kirwan et al. 2001, Olmos et al. 1997).

That part of the EBA on the left bank of the middle reaches of the São Francisco has recently been demonstrated to be of high importance for several threatened and endemic taxa of the São Francisco basin (Kirwan et al. 2001), and we cannot eliminate the possibility that $P$. roquettei is present in these areas, albeit presumably at low densities. Indeed, a 1997 sighting was reported from Cavernas do Peruaçu National Park by Stattersfield et al. (1998). We consider that this observation must be regarded as uncertain for now. JMB, one of the observers of the individual in question, has since gained unequivocal experience of roquettei; given the lack of specimen, photographic or sound evidence to support the 1997 sighting, and that we have subsequently used playback of the species' vocalizations in the same and additional areas of Cavernas do Peruaçu to no avail (see Other fieldwork), the record appears best considered as requiring corroboration. Nonetheless, some forests within this region may prove suitable for roquettei and, despite unsuccessful searches for it in 1985-1987 (BirdLife International 2000) and 1997-2002 (JMB and GMK pers. obs.), we urge future workers to continue surveying relevant habitats in the area.

While protected by Brazilian law (Paiva 1999), a conservation strategy is urgently required for the species and the many other endangered forms found in the area (Stattersfield et al. 1998, Kirwan et al. 2001), but even more importantly it is needed to protect representative tracts of forested biomes in the São Francisco basin. We urge the implementation of more thorough surveys around Pirapora and in the Itacarambí area, and that tracts of deciduous and gallery forests within intervening areas be identified and investigated in order to locate new populations of the species and other poorly known and threatened taxa, particularly Moustached Woodcreeper. In addition to the targets proposed by BirdLife International (2000), we suggest that protection of gallery forests in the region requires legal reinforcement and should be considered an essential part of land management in the area. The EBA and its surrounds should also be surveyed in order to identify localities suitable for reserve status, as within the region only Cavernas do Peruaçu National Park currently receives any protection.

Environmental awareness and education campaigns directed at schools in the region should be planned; ecological research is necessary to establish sound conservation and management strategies in the region, as are studies of several of the threatened and poorly known species that occur within the area, including P. roquettei. 


\section{Acknowledgements}

We thank Heinz Remold and Edwin O. Willis for permission to include details of their record in November 1998, and Bret Whitney, Douglas Stotz, Bennett Hennessey and John Sterling for discussing systematic issues and/or providing life-history details for P. parkeri, and David Beadle for discussing the behaviour of $P$. flaviventris. An anonymous reviewer and the editor, Seb Buckton, made a number of pertinent comments on the submitted manuscript. JMB and GMK are particularly grateful to their fellow observers during a December 1999 visit to the São Francisco Valley, Jeremy Minns and Marco della Seta, GMK to Beadle, Arthur Grosset and Minns in February 2002, and Mark Elwonger and others (1998) and Robert Williams (1997) for their assistance in previous years.

\section{References}

Ab'Saber, A. N. (1964) O relevo brasileiro e seus problemas. In A. Azevedo, ed. Brasil: a terra e o homem. São Paulo: Companhia Ed. Nacional.

Ab'Saber, A. N. (1977) Espaços ocupados pela expansão dos climas secos na América do Sul, por ocasião dos períodos glaciais quaternários. Paleoclimas 3: 1-19.

BirdLife International (2000) Threatened birds of the world. Cambridge, U.K.: BirdLife International and Barcelona: Lynx Edicions.

Clay, R. P., Tobias, J. A., Lowen, J. C. and Beadle, D. (1998) Field identification of Phylloscartes and Phyllomyias tyrannulets in the Atlantic Forest region. Cotinga 10: 82-95.

Collar, N. J., Gonzaga, L. P., Krabbe, N., Madroño Nieto, A., Naranjo, L. G., Parker, T. A. and Wege, D. C. (1992) Threatened birds of the Americas: the ICBP/IUCN Red Data Book. Cambridge, U.K.: International Council for Bird Preservation.

Fitzpatrick, J. W. and Stotz, D. F. (1997) A new species of tyrannulet (Phylloscartes) from the Andean foothills of Peru and Bolivia. Orn. Monogr. 48: 37-44.

Hartt, C. F. (1870) Geology and physical geography of Brazil. In L. Agassiz. Scientific results of a journey in Brazil. Boston: Fields, Osgood and Co.

Hilty, S. L. and Brown, W. L. (1986) A guide to the birds of Colombia. Princeton, N.J.: Princeton University Press.

Kirwan, G. M., Mazar Barnett, J. and Minns, J. (2001) Significant ornithological observations from the rio São Francisco Valley, Minas Gerais, Brazil, with notes on conservation and biogeography. Ararajuba 9: 145-161.

Olmos, F., Martuscelli, P. and Silva e Silva, R. (1997) Distribution and dry-season ecology of Pfrimer's Conure Pyrrhura pfrimeri, with a reappraisal of Brazilian Pyrrhura "leucotis". Orn. Neotrop. 8: 121-132.

Paiva, M. P. (1999) Conservação da fauna brasileira. Rio de Janeiro: Ed. Interciência.

Pennington, R. T., Prado, D. E. and Pendry, C. A. (2000) Neotropical seasonally dry forests and Quaternary vegetation changes. J. Biogeogr. 27: 261-273.

Pimentel, M. (1997) Projeto Jaíba: onde o sertão começa a virar mar. Manchete Rural (Especial Março): 24-30.

Raposo, M. A. (1997) A new species of Arremon (Aves: Emberizidae) from Brazil. Ararajuba 5: 1-9.

Ratter, J. A., Askew, G. P., Montgomery, R. F. and Gifford, D. R. (1978) Observations on forests of some mesotrophic soils in central Brazil. Rev. bras. Bot. 1: 47-58.

Remsen, J. V. and Robinson, S. K. (1990) A classification scheme of foraging behavior of birds in terrestrial habitats. Stud. Avian Biol. 13: 144-16o. 
Remsen, J. V., Rocha, O., Schmitt, C. G. and Schmitt, D. C. (1991) Zoogeography and geographic variation of Platyrinchus mystaceus in Bolivia and Peru, and the circumAmazonian distribution pattern. Orn. Neotrop. 2: 77-83.

Ribon, R. and Simon, J. E. (1997) Avifauna da região do Projeto Jaíba, Médio Rio São Francisco, Minas Gerais. P. 31 in Resumos, VI Congresso Brasileiro de Ornitologia, Belo Horizonte (MG).

Ridgely, R. S. and Tudor, G. (1994) The birds of South America, 2. The suboscine passerines. Oxford, U.K.: Oxford University Press.

de Schauensee, R. M. and Phelps, W. H. (1978) A guide to the birds of Venezuela. Princeton, N.J.: Princeton University Press.

Silva, J. M. C. (1989) Análise biogeográfica da avifauna das florestas do interflúvio Araguaia-São Francisco. M.Sc. dissertation, University of Brasília.

Silva, J. M. C. (1992) Phylogeny of the Cercomacra nigricans species group (Aves: Thamnophilidae) and the biogeographical importance of Pliocene-Pleistocene tectonic movements. Goeld. Zool. 18: 1-8.

Silva, J. M. C. (1996) New data support the specific status of Reiser's Tyrannulet, a central Brazilian endemic. Bull. Brit. Orn. Club 116: 109-113.

Silva, J. M. C. (1997) Endemic bird species and conservation in the Cerrado region, South America. Biodiv. Conserv. 6: 435-450.

Silva, J. M. C. and Oren, D. C. (1992). Notes on Knipolegus franciscanus Snethlage, 1928 (Aves: Tyrannidae), an endemism of central Brazilian dry forests. Goeld. Zool. 16: 1-9.

Silva, J. M. C. and Oren, D. C. (1997) Geographic variation and conservation of the Moustached Woodcreeper Xiphocolaptes falcirostris, an endemic and threatened species of north-eastern Brazil. Bird Conserv. Internatn. 7: 263-274.

Silva, J. M. C. and Straube, F. C. (1997) Systematics and biogeography of Scaled Woodcreepers (Aves: Dendrocolaptidae). Stud. Neotrop. Fauna and Environ. 31: 3-10.

Smithe, F. B. (1975) Naturalist's color guide. New York: American Museum of Natural History.

Snethlage, E. (1928) Neue Vogelarten und Unterarten aus Innerbrasilien. J. Orn. 76: 581587 .

Stattersfield, A. J., Crosby, M. J., Long, A. J. and Wege, D. C. (1998) Endemic Bird Areas of the world: priorities for biodiversity conservation. Cambridge, U.K.: BirdLife International (BirdLife Conserv. Series 7).

Stiles, F. G. and Skutch, A. F. (1989) A guide to the birds of Costa Rica. Ithaca, NY: Cornell University Press.

Wetmore, A. (1972) The birds of the Republic of Panama, 3. Passeriformes: Dendrocolaptidae (woodcreepers) to Oxyruncidae (Sharpbills). Washington, DC: Smithsonian Institution Press.

Whitney, B. M., Pacheco, J. F., Fonseca, P. S. M., Webster, R. E., Kirwan, G. M. and Mazar Barnett, J. (in press) Reassignment of Chordeiles vielliardi Lencioni-Neto, 1994, to Nyctiprogne Bonaparte, 1854, with comments on the latter genus and some presumably related chordeilines (Aves: Caprimulgidae). Bull. Brit. Orn. Club.

Willis, E. O. and Oniki, Y. (1991) Avifaunal transects across the open zones of northern Minas Gerais, Brazil. Ararajuba 2: 41-58.

\section{MARCOS A. RAPOSO}

Depto. Zoologia, Instituto de Biociências, Universidade de São Paulo, Rua do Matão 101, Trav. 14, Edif. Zoologia, 05508-900, São Paulo, SP, Brazil. E-mail: mraposo@antares.com.br

JUAN MAZAR BARNETT

Av. Forest $15311^{\circ} \mathrm{B},(1430)$ Buenos Aires, Argentina. 
GUY M. KIRWAN

74 Waddington Street, Norwich NR2 4JS, U.K.

\section{RICARDO PARRINI}

Rua Desembargador Isidro 126, Bl. C, ap. 801, 20521-16o Rio de Janeiro, RJ, Brasil. E-mail:rparrini@hotmail.com.br.

Received 20 August 2001; revision accepted 25 April 2002 